\title{
Pengaruh umur larva terhadap kualitas ratu yang dihasilkan pada penangkaran lebah ratu Apis cerana L. (Hymenoptera: Apidae) dengan teknik pencangkokan
}

\author{
Effect of larval ages on the quality of Apis cerana L. \\ (Hymenoptera: Apidae) queens breed in captivity using \\ queen-grafting technique
}

\author{
Kuntadi* \\ Pusat Penelitian dan Pengembangan Konservasi dan Rehabilitasi. Badan Penelitian dan \\ Pengembangan Kehutanan. Jalan Gunung Batu 5, Bogor 16610
}

(diterima Maret 2012, disetujui September 2012)

\begin{abstract}
ABSTRAK
Percobaan teknik cangkok berbagai umur larva lebah madu Apis cerana L. ditujukan untuk mengetahui potensi kualitas ratu yang akan dihasilkan. Empat perlakuan larva umur 1, 2, 3, dan 4 hari diaplikasikan pada uji coba pencangkokan, masing-masing sebanyak 5 mangkok ratu di setiap koloni percobaan. Dalam penelitian ini digunakan 5 koloni lebah madu A. cerana sebagai ulangan percobaan. Bobot pupa digunakan sebagai indikator potensi reproduktivitas ratu yang akan dihasilkan. Hasil penelitian menunjukkan bahwa umur larva berpengaruh terhadap tingkat penerimaan larva yang dicangkokan dan bobot pupa calon ratu. Tingkat penerimaan larva lebih tinggi pada larva muda dibandingkan dengan larva yang lebih tua sebagaimana ditunjukkan oleh jumlah perkembangan sel ratu yang berhasil dierami. Jumlah rata-rata sel yang berkembang menjadi sel ratu dari hasil pencangkokan larva umur 1, 2, 3, dan 4 hari berturut-turut sebanyak 4,4 $\pm 1,1 \mathrm{sel} /$ koloni, 3,4 $\pm 1,1 \mathrm{sel} / \mathrm{koloni}, 2,0 \pm 1,0 \mathrm{sel} / \mathrm{koloni}$, dan 2,4 $\pm 0,5 \mathrm{sel} / \mathrm{koloni}$. Larva umur 1 dan 2 hari menghasilkan pupa dengan bobot yang lebih berat dari pada yang berasal dari larva umur 3 dan 4 hari. Larva umur 1, 2, 3, dan 4 hari berturut-turut menghasilkan pupa dengan berat rata-rata 153,33 $\pm 4,48 \mathrm{mg} / \mathrm{individu}, 149,14 \pm 6,29 \mathrm{mg} / \mathrm{individu}, 126,17 \pm 7,28 \mathrm{mg} / \mathrm{individu}$, dan $126,70 \pm 7,61 \mathrm{mg} /$ individu. Tidak ada perbedaan bobot pupa antara hasil pencangkokan dengan larva umur 1 dan 2 hari dan antara larva umur 3 dan 4 hari. Dengan demikian, larva umur 1 dan 2 hari berpotensi menghasilkan lebah ratu yang lebih berkualitas dibandingkan dengan larva umur 3 dan 4 hari.
\end{abstract}

Kata kunci: Apis cerana, pencangkokan, umur larva, tingkat penerimaan, bobot pupa

\begin{abstract}
An experimental study to find out the effect of larval ages to the quality of queens produced through queen-grafting technique has been done in Apis cerana colony. Each of four larval ages (1-4 day-old larvae) was grafted into 5 queen cups in every single colony. Five colonies were used in the study as experimental replications. Pupal weight was used as initial indicator of potential reproductivity of upcoming queen. The results showed that larval age affected both the acceptance rate of grafted larvae and queen pupal weight. The acceptance rate of young larvae was higher than old larvae as shown by their successful number of capped queen cells development. The mean number of capped queen cells developed from larvae at the age of 1,2,3, and 4 day-old were $4.4 \pm$ 1.1 cells/colony, $3.4 \pm 1.1$ cells/colony, $2.0 \pm 1.0$ cells/colony, and $2.4 \pm 0.5$ cells/colony, respectively. The queens reared from 1 and 2 day-old larvae significantly had heavier pupae than those from both
\end{abstract}

\footnotetext{
*Penulis korespondensi: Kuntadi. Pusat Penelitian dan Pengembangan Konservasi dan Rehabilitasi, Badan Litbang Kehutanan,

Jalan Gunung Batu 5, Bogor 16610

Tel: 0251-8315222, Faks: 0251-8638111, Email: kuntadi10@yahoo.com
} 
3 and 4 day-old larvae. The mean pupal weight grafted from 1,2, 3 day, and 4 day old larvae were $153.33 \pm 4.48 \mathrm{mg} /$ pupae, $149.14 \pm 6.29 \mathrm{mg} /$ pupae, $126.17 \pm 7.28 \mathrm{mg} /$ pupae, and $126.70 \pm 7.61 \mathrm{mg} /$ pupae, respectively. There were no differences between pupal weight grafted from 1 and 2 day-old larvae and between pupal weight grafted from 3 and 4 day-old larvae. The study showed that 1 and 2 day-old grafted larvae potentialy produced better quality queens than those of older larvae.

Key words: Apis cerana, grafting, age of larvae, acceptance rate, queen pupal weight

\section{PENDAHULUAN}

Apis cerana L. adalah jenis lebah madu Asia yang sebarannya meliputi sebagian besar wilayah Indonesia (Ruttner 1988). Tradisi budi daya $A$. cerana telah lama dilakukan masyarakat dengan cara sederhana (Hadisoesilo 1993). Kendala utama di dalam budi daya $A$. cerana antara lain produktivitas rendah, kecenderungan hijrah tinggi, dan agresif (Kuntadi 2001; Kuntadi 2005; Kuntadi 2008). Diperlukan proses seleksi koloni dan reproduksi induk secara berkelanjutan untuk dapat memperbaiki kualitas dan produktivitas koloni lebah madu (Kuntadi 2007; Woodward 2010).

Lebah ratu berperan sangat penting di dalam koloni lebah madu. Fungsi reproduksi menjadikan lebah ratu sebagai induk yang menentukan sifat dan karakter seluruh anggota koloni, baik secara individu maupun kolektif. Lebah ratu juga berfungsi menjaga kestabilan dan keharmonisan koloni (colony homeostasis). Namun, peran dan fungsi lebah ratu di dalam koloni dibatasi oleh faktor umur. Masa produktif lebah ratu paling lama dua sampai empat tahun, bahkan tidak jarang hanya satu tahun (Punchihewa 1994). Efektivitas kepemimpinan ratu semakin turun seiring waktu, sehingga suatu saat akan digantikan oleh ratu baru keturunannya.

Penggantian lebah ratu merupakan kegiatan rutin di dalam budi daya lebah madu modern untuk menjaga agar koloni tetap stabil, sehat, dan produktif. Penangkaran dan penggantian lebah ratu secara rutin telah dipraktekkan sejak lama pada budi daya lebah madu asal Eropa ( $A$. mellifera). Penangkaran lebah ratu pada umumnya menggunakan teknik cangkok larva karena memungkinkan untuk memproduksi lebah ratu dalam jumlah dan waktu tidak terbatas.

Keberhasilan teknik cangkok larva diukur dari dieraminya larva hingga menjadi lebah ratu untuk setiap sel ratu yang disediakan dan dari produktivitas lebah ratu yang dihasilkan. Meskipun produktivitas lebah ratu pada akhirnya ditentukan oleh keberhasilan proses perkawinannya, yakni seberapa banyak pejantan yang mengawini dan seberapa banyak volume sperma yang dapat diperoleh, namun perkembangan organ reproduksi pada awal pengeraman calon lebah ratu juga berpengaruh kepada kemampuan reproduksinya. Menurut Gąbka et al. (2011), kemampuan bertelur lebah ratu bergantung pada kapasitas indung telur (ovarium) dan volume kantong sperma (spermateka) pada organ reproduksinya. Semakin besar volume indung telur akan semakin banyak tabung telur (ovariol) di dalamnya sehingga semakin besar jumlah telur yang dapat dihasilkan. Sementara itu, semakin besar volume kantung sperma semakin banyak sperma lebah jantan yang dapat disimpan untuk cadangan pembuahan. Penangkaran ratu harus dapat menghasilkan calon lebah ratu yang memiliki organ reproduksi dengan kapasitas besar sehingga berpotensi tumbuh dan berkembang menjadi lebah ratu produktif.

Perkembangan lebah ratu ditentukan oleh faktor nutrisi, baik jumlah maupun komposisinya. Menurut Winston (1987), larva yang mendapat royal jelly lebih banyak dengan kandungan utama berasal dari sekresi kelenjar mandibula akan berkembang menjadi individu dengan karakteristik lebah ratu. Sebaliknya, larva yang mendapat royal jelly dalam jumlah sedikit dengan kandungan utama lebih banyak berasal dari kelenjar hipofaring akan berkembang menjadi individu yang memiliki karakteristik lebah pekerja. Jumlah dan komposisi royal jelly yang diberikan oleh lebah pekerja bergantung pada bentuk dan ukuran sel tempat larva berkembang.

Teknik cangkok larva pada dasarnya adalah pemindahan larva dari sel lebah pekerja ke sel lebah ratu yang ukurannya lebih besar sehingga umur larva menjadi faktor dominan yang menentukan jumlah dan komposisi royal jelly yang diterima. Hal ini berhubungan dengan jangka waktu dalam menyelesaikan stadium 
larva. Semakin tua umur larva yang dicangkokan, semakin pendek waktu yang dibutuhkan untuk menyelesaikan stadium larva yang tersisa, dan semakin sedikit pula jumlah royal jelly yang dikonsumsi.

Lebah ratu dapat dihasilkan melalui teknik pencagkokan dengan larva sampai umur 3 hari (Gencer et al. 2000), meskipun kualitas ratu akan semakin turun dengan bertambahnya umur larva. Hasil penelitian pada lebah madu A. mellifera menunjukkan bahwa ratu yang dihasilkan dari larva tua memiliki jumlah ovariol di masing-masing indung telur yang lebih sedikit dan bobot badan yang lebih ringan dibandingkan dengan ratu yang diproduksi dari larva yang lebih muda (Winston 1987; Tarpy et al. 2000). Gencer et al. (2000) mengatakan bahwa lebah ratu hasil pencangkokan larva umur 1 hari memiliki bobot badan yang lebih berat dan produksi telur yang lebih banyak daripada yang dihasilkan dari larva umur 2 hari, akan tetapi tingkat penerimaan koloni (acceptance rate) lebih tinggi pada pencangkokan dengan larva umur 2 hari. Menurut Winston (1987), umur larva empat hari menjadi batas penentuan jenis individu yang akan dilahirkan. Larva yang ditransfer pada umur empat hari hanya sedikit yang bertahan dan biasanya individu yang lahir lebih menyerupai lebah pekerja, tetapi memiliki beberapa karakter lebah ratu.

Secara biologis, fase perkembangan lebah ratu A. cerana identik dengan lebah ratu A. mellifera. Teknik pencangkokan juga memungkinkan untuk diterapkan pada lebah madu ini sebagaimana hasil uji coba oleh Wongsiri et al. (1990) dan Kuntadi (2010). Namun, karena sel sarang yang sempit dan ukuran larva $A$. cerana pada awal perkembangannya sangat kecil sehingga cukup sulit memindahkan larva ke sel ratu. Larva yang lebih besar akan cenderung lebih mudah dalam pelaksanaan proses pencangkokan. Berkaitan dengan hal tersebut, telah dilakukan penelitian aplikasi teknik pencangkokan dengan umur larva yang berbeda untuk penangkaran lebah ratu A. cerana. Fokus penelitian bertujuan untuk mengetahui umur larva A. cerana yang tepat untuk pencangkokan, yaitu secara teknis mudah dipindahkan, secara biologis memiliki acceptance rate tinggi, dan secara kualitas berpontensi menghasilkan lebah ratu yang berkualitas.

\section{BAHAN DAN METODE}

Penelitian dilakukan di area arboretum Pusat Penelitian dan Pengembangan Konservasi dan Rehabilitasi, Badan Penelitian dan Pengembangan Kehutanan, di Bogor pada bulan Agustus dan September 2010. Sembilan buah koloni lebah madu A. cerana yang dipelihara dengan kotak eram berukuran $35 \mathrm{~cm}$ x $31 \mathrm{~cm}$ x $25 \mathrm{~cm}$ (panjang $\mathrm{x}$ lebar $\mathrm{x}$ tinggi) dipersiapkan khusus untuk penelitian ini. Lima koloni digunakan sebagai unit percobaan, empat koloni sisanya digunakan sebagai penyedia larva.

Eksperimen teknik cangkok larva dilakukan menurut rancangan acak lengkap dengan 4 perlakuan dan 5 ulangan. Perlakuan terdiri atas empat tingkat umur larva, yaitu 1, 2, 3, dan 4 hari. Masing-masing perlakuan diuji pada 5 buah mangkok ratu di setiap koloni percobaan sehingga di dalam 1 koloni terdapat 20 buah mangkok ratu yang berisi larva dengan 4 macam golongan umur. Di dalam penelitian ini digunakan 5 koloni $A$. cerana sebagai ulangan percobaan.

Mangkok ratu dibuat dari lilin lebah dengan ukuran diameter $6 \mathrm{~mm}$, tebal dinding $1 \mathrm{~mm}$, dan kedalaman $7 \mathrm{~mm}$. Mangkok ratu dipasang pada bingkai khusus yang disebut bingkai cangkok dan dapat diletakkan di antara bingkai sarang. Setiap bingkai berisi 20 mangkok yang disusun dalam dua baris sehingga masing-masing baris berisi 10 buah mangkok. Selanjutnya, kelima bingkai cangkok dimasukkan ke masing-masing koloni eram selama satu hari agar lebah mengenali aroma mangkok ratu.

Larva yang digunakan untuk pencangkokan berasal dari satu koloni supaya perkembangan awal setiap individu larva relatif sama karena berasal dari satu induk ratu dan dipelihara oleh koloni yang sama. Umur larva ditentukan berdasarkan ukuran tubuh setelah sebelumnya dilakukan pengamatan dengan mengikuti perkembangan larva sejak menetas dari telur.

Metode cangkok lava mengikuti prosedur yang biasa dilakukan di penangkaran komersial (Laidlaw 1979). Pencangkokan dilakukan serempak untuk semua umur larva. Dalam penelitian ini digunakan metode cangkok kering (dry grafting), yaitu tanpa pemberian cairan starter pada setiap mangkok ratu (Tarpy et al. 2004). Larva diambil 
menggunakan alat khusus kemudian dimasukkan ke dalam mangkok ratu. Setiap bingkai cangkok yang telah diisi larva sesuai jenis perlakuan dan jumlah yang dibutuhkan dimasukkan ke dalam koloni pengeraman, diletakkan di bagian tengah di antara dua sarang eram. Koloni pengeraman terlebih dahulu dihilangkan ratunya supaya larva di setiap mangkok ratu diterima dan dipelihara sebagai calon lebah ratu oleh lebah pekerja anggota koloni.

Pengamatan mulai dilakukan pada hari ke-6 setelah pencangkokan, yaitu pada saat semua sel ratu yang dipelihara telah berkembang ke stadia pupa. Pada tahap ini dilakukan pengukuran tingkat keberhasilan pencangkokan pada masing-masing perlakuan dengan menghitung rata-rata jumlah sel ratu yang terbentuk dari setiap koloni percobaan. Selanjutnya, sel ratu diperiksa setiap hari sampai ditemukannya tanda lebah ratu hampir menetas, yaitu tutup sel menjadi halus dan berwarna coklat. Setiap sel ratu yang memperlihatkan tanda tersebut diambil dan pupanya ditimbang.

Sidik ragam dan uji Tukey digunakan untuk melihat pengaruh perlakuan umur larva terhadap tingkat keberhasilan pengeraman calon ratu hasil pencangkokan dan bobot calon ratu.

\section{HASIL}

Sebanyak 61 sel (61\%) dierami hingga stadia pupa dari 100 sel ratu yang dicangkok dengan larva dari 4 kelompok umur. Berdasarkan kelompok umur larva berturut-turut 1, 2, 3, dan 4 hari, jumlah sel ratu yang berhasil dierami hingga stadia pupa sebanyak 22 (88\%), 17 (68\%), 10 (40\%), dan 12 (48\%) buah. Tabel 1 memperlihatkan rata-rata jumlah sel ratu yang dierami hingga stadia pupa di setiap koloni percobaan dan ratarata bobot pupa yang dihasilkan dari masingmasing perlakuan umur larva.
Hasil sidik ragam menunjukkan adanya perbedaan antarperlakuan umur larva terhadap rata-rata jumlah sel pupa ratu yang terbentuk dari setiap koloni percobaan $(\mathrm{P}<0,01)$. Berdasarkan uji Tukey terlihat bahwa tingkat keberhasilan pencangkokan larva umur 1 hari lebih tinggi daripada larva umur 3 dan 4 hari. Antara larva umur 3 dan 4 hari tidak ada perbedaan tingkat keberhasilan pencangkokan, demikian juga antara pencangkokan larva umur 1 dan 2 hari.

Hasil analisis ragam pada data bobot per individu pupa menunjukkan adanya perbedaan yang sangat nyata antara perlakuan umur larva $(\mathrm{P}$ $<0,01)$. Hasil uji Tukey memperlihatkan bahwa pupa calon ratu yang berasal dari larva umur 1 dan 2 hari lebih berat daripada pupa calon ratu yang berasal dari larva umur 3 dan 4 hari. Hasil pencangkokan antara larva umur 1 dan 2 hari tidak menunjukkan adanya perbedaan pada bobot pupa calon ratu, demikian juga antara larva umur 3 dan 4 hari.

\section{PEMBAHASAN}

Jumlah rata-rata sel ratu yang berkembang menjadi pupa calon ratu dari setiap umur larva yang dicangkokkan memperlihatkan adanya kecenderungan koloni lebah madu $A$. cerana memilih larva yang lebih muda dalam pembentukan calon ratu. Kecenderungan seperti ini juga terjadi pada lebah madu A. mellifera, baik yang murni ras Afrika, Eropa, maupun hasil persilangannya. Penelitian Hatch et al. (1999) dan Schneider \& DeGrandi-Hoffman (2002) yang mengamati perkembangan alami pembentukan calon ratu dalam kondisi darurat pada koloni $A$. mellifera ras Afrika, Eropa, dan persilangannya menunjukkan kecenderungan tersebut. Dikatakan oleh Hatch et al. (1999), lebah pekerja lebih suka merusak sel ratu yang dibangun dari larva

Tabel 1. Rata-rata jumlah sel ratu yang berkembang sampai stadia pupa pada setiap koloni dan rata-rata bobot pupa yang dihasilkan dari masing-masing umur larva yang dicangkokkan

\begin{tabular}{lcccc}
\hline $\begin{array}{l}\text { Umur larva } \\
\text { (hari) }\end{array}$ & $\begin{array}{c}\text { Jumlah } \\
\text { pencangkokan }\end{array}$ & $\begin{array}{c}\text { Jumlah pupa ratu yang } \\
\text { terbentuk }\end{array}$ & $\begin{array}{c}\text { Jumlah sel pupa ratu per } \\
\text { koloni* }\end{array}$ & $\begin{array}{c}\text { bobot pupa ratu per individu } \\
\text { (mg/individu)* }\end{array}$ \\
\hline 1 & 25 & 22 & $4,4 \pm 1.1 \mathrm{a}$ & $153,33 \pm 4,88 \mathrm{a}$ \\
2 & 25 & 17 & $3,4 \pm 1,1 \mathrm{ab}$ & $149,14 \pm 6,29 \mathrm{a}$ \\
3 & 25 & 10 & $2,0 \pm 1,0 \mathrm{~b}$ & $126,17 \pm 7,28 \mathrm{~b}$ \\
4 & 25 & 12 & $2,4 \pm 0,5 \mathrm{~b}$ & $126,70 \pm 7,61 \mathrm{~b}$ \\
\hline
\end{tabular}

*Angka pada kolom yang sama yang diikuti oleh huruf yang sama menyatakan tidak beda nyata dengan uji Tukey pada taraf $1 \%$ 
yang lebih tua. Sejalan dengan hal tersebut, hasil penelitian ini memperlihatkan bahwa tingkat keberhasilan pengeraman lebah ratu lebih tinggi pada pencangkokan dengan larva muda.

Pengamatan terhadap bobot pupa menunjukkan pencangkokan larva muda menghasilkan pupa dengan bobot yang lebih berat daripada pupa yang berasal dari larva tua. Hasil ini mirip dengan hasil penelitian yang dilakukan pada lebah madu A. mellifera (Hatch et al. 1999; Gencer et al. 2000; Gilley et al. 2003; Emsen 2004). Menurut Schneider \& DeGrandi-Hoffman (2002), sel ratu yang berisi larva muda lebih banyak dikunjungi dan dierami lebah pekerja sehingga tingkat keberhasilannya menjadi lebih besar. Larva yang lebih muda akan berkembang lebih sempurna. Hal ini disebabkan oleh makin lamanya masa kunjungan dan pemberian makanan oleh lebah pekerja sehingga larva muda mendapatkan porsi makanan royal jelly yang lebih banyak.

Jangka waktu masa pengeraman dan pemberian makanan yang lebih banyak selama masa perkembangan larva berpengaruh positif pada bobot pupa calon ratu. Semakin muda umur larva atau semakin lama masa pengeraman larva, maka semakin berat bobot pupa yang dihasilkannya. Hasil penelitian ini sejalan dengan apa yang dikatakan oleh Gencer et al. (2000) bahwa setiap penambahan 1 hari umur larva yang dicangkok akan mengurangi bobot tubuh, diameter dan volume spermateka, dan jumlah ovariol calon ratu yang dihasilkan. Hasil penelitian Gilley et al. (2003) mengkonfirmasi hal tersebut, yaitu perkembangan fisik calon ratu yang berkembang dari larva lebih muda memiliki lebar toraks, diameter spermateka, dan bobot ovarium yang lebih besar dibandingkan dengan individu calon ratu yang berasal dari larva tua. Dengan demikian, teknik pencangkokan dengan larva muda akan menghasilkan calon ratu dengan kualitas yang lebih tinggi, karena memiliki ukuran tubuh yang relatif lebih besar dan bobot lebih berat yang memungkinkan memiliki jumlah ovariol dan daya simpan sperma yang lebih banyak. Hal ini dibuktikan oleh Emsen (2004) dan Akyol et al. (2008) yang menemukan adanya korelasi positif antara bobot tubuh lebah ratu dengan jumlah spermatozoa di dalam spermateka dan tingkat penelurannya. Temuan ini sejalan dengan hasil penelitian Gencer et al. (2000) yang menemukan bahwa lebah ratu yang bobotnya lebih berat menghasilkan sarang anakan yang lebih luas dibandingkan dengan ratu dengan bobot yang lebih ringan.

\section{KESIMPULAN}

Umur larva dalam teknik pencangokan berpengaruh terhadap tingkat keberhasilan perkembangan calon ratu dan bobot pupa calon ratu yang dihasilkan. Larva umur 1 dan 2 hari menghasilkan tingkat penerimaan yang lebih tinggi dibandingkan dengan larva yang berumur lebih tua dalam penangkaran ratu $A$. cerana dengan teknik pencangkokan, sebagaimana ditunjukkan oleh tingkat keberhasilannya mencapai stadia pupa. Larva umur 1 dan 2 hari juga menghasilkan bobot pupa yang lebih berat dibandingkan dengan larva umur 3 dan 4 hari sehingga diperkirakan memiliki kualitas ratu yang lebih baik.

\section{DAFTAR PUSTAKA}

Akyol E, Yeninar H, Kaftanoglu O. 2008. Life weight of queen honey bees (Apis mellifera L.) predicts reproductive characteristics. Journal of the Kansas Entomological Society 81:92-100. http://dx.doi.org/10.2317/JKES-705.13.1.

Emsen B. 2004. Relationship between larval age and characteristics of queen honey bees (Apis mellifera L.) after single and double grafting. In: Bernardinelli I, Milani N. (eds.), Proceeding of the $1^{\text {st }}$ European Conference of Apidologie (Abstract) (Udine, 19-23 September 2004). pp. 66. Udine: Arti Grafiche Friulane SpA.

Gąbka J, Ochnio M, Kamińsky Z, Majewska M. 2011. Effect of age of eggs used for rearing honey bee queens on the number of received queen cells. Journal of Apicultural Science 55:47-53.

Gencer HV, Shah SQ, Firatli C. 2000. Effects of supplemental feeding of queen rearing colonies and larval age on the acceptance of grafted larvae and queen traits. Pakistan Journal of Biological Sciences 3:1319-1322. http://dx.doi.org/10.3923/ pjbs.2000.1319.1322.

Gilley DC, Tarpy DR, Land BB. 2003. Effect of queen quality on interactions between workers and dueling queens in honeybee (Apis mellifera L.) colonies. Behavioral Ecology and Sociobiology 55:190-196. http://dx.doi.org/10.1007/s00265003-0708-y. 
Hadisoesilo S. 1993. Evolutionary and development of beekeeping in Indonesia. In: Proceeding of the Beenet Asia Workshop on Priorities in $R \& D$ on Beekeeping in Tropical Asia (Kuala Lumpur, 1992). pp. 39-44. Malaysia: Beenet Asia, Universiti Pertanian Malaysia, Southbound.

Hatch D, Tarpy DR, Fletcher DJC. 1999. Worker regulation of emergency queen rearing in honey bee colonies and the resultant variations in queen quality. Insectes Sociaux 46:372-377. http:// dx.doi.org/10.1007/s000400050159.

Kuntadi. 2001. Perilaku hijrah koloni lebah madu Apis cerana (Hymenoptera: Apidae). In: Sukartana P et al. (Eds), Pengelolaan Serangga yang Bijaksana Menuju Optimasi Produksi. Prosiding Seminar Nasional III Perhimpunan Entomologi Indonesia Cabang Bogor (Bogor, 6 November 2001). pp. 267-271. Bogor: Perhimpunan Entomologi Indonesia Cabang Bogor.

Kuntadi. 2005. Aspek teknis dalam pemuliaan bibit lebah madu Apis cerana. Info Hutan 2:281-290.

Kuntadi. 2007. Teknik pemuliaan lebah madu Apis cerana dengan pola partisipatif. In: Gintings $\mathrm{N}$ et al. (Eds.), Pemanfaatan Iptek untuk Kesejahteraan Masyarakat. Prosiding Gelar Teknologi (Purworejo, 30-31 Oktober 2007). pp. 157-165. Bogor: Pusat Penelitian dan Pengembangan Hutan dan Konservasi Alam.

Kuntadi. 2008. Perbandingan tiga cara uji untuk mengukur agresivitas koloni lebah madu Apis cerana. Info Hutan 5:355-363.

Kuntadi. 2010. Uji coba cangkok basah (wet grafting) dalam penangkaran lebah ratu Apis cerana L. In: Kardinan A et al. (Eds.), Peranan Entomologi dalam Mendukung Pengembangan Pertanian Ramah Lingkungan dan Kesehatan Masyarakat. Prosiding Seminar Nasional VI Perhimpunan
Entomologi Indonesia (Bogor, 24 Juni 2010). pp. 66-73. Bogor: Perhimpunan Entomologi Indonesia Cabang Bogor.

Laidlaw Jr H. 1979. Contemporary Queen Rearing. Hamilton: Dadant Publication.

Punchihewa RWK. 1994. Beekeeping for Honey Production in Sri Lanka; Management of Asiatic Hive Honeybee Apis cerana in Its Natural Tropical Monsoonal Environment. Sri Lanka Department of Agriculture: Peradeniya, Sri Lanka.

Ruttner F. 1988. Biogeography and Taxonomy of Honeybees. Springer-Verlag, Berlin, Heidelberg, New York, London, Paris, Tokyo. http://dx.doi. org/10.1007/978-3-642-72649-1.

Schneider SS, DeGrandi-Hoffman G. 2002. The influence of worker behavior and paternity on the development and emergence of honey bee queens. Insectes Sociaux 49:306-314. http:// dx.doi.org/10.1007/PL00012653.

Tarpy DR, Hatch S, Fletcher DJC. 2000. The influence of queen age and quality during queen replacement in honeybee colonies. Animal Behaviour 59:97-101. http://dx.doi.org/10.1006/ anbe.1999.1311.

Tarpy DR, Gilley DC, Seeley TD. 2004. Levels of selections in a social insect: a review of conflict and cooperation during honey bee (Apis mellifera) queen replacement. Behavioral Ecology and Sociobiology 55:513-523. http:// dx.doi.org/10.1007/s00265-003-0738-5.

Winston ML. 1987. The Biology of the Honey Bee. London: Harvard Univ. Press.

Wongsiri S, You-Sheng L, Sylvester HA. 1990. Queen rearing with Apis cerana. American Bee Journal 130:32-35.

Woodward D. 2010. Queen Bee: Biology, Rearing and Breeding. Balclutha: Northern Bee Books. 